\title{
ASSESSING THE RISK OF ROOT ROTS IN GOMMON BEANS IN EAST AFRICA USING SIMULATED, ESTIMATED AND OBSERVED DAILY RAINFALL DATA
}

\author{
By ANDREW FARROW $\dagger, \ddagger$, DIDACE MUSONI $\dagger, \S$, SIMON COOK $\dagger, \boldsymbol{\uparrow}$, and \\ ROBIN BURUCHARA $\dagger$ \\ $\dagger$ †LAT-Africa, Kawanda Agricultural Research Institute, Km13 Bombo Road, Kampala, Uganda
}

(Accepted 29 October 2010)

\begin{abstract}
SUMMARY
This paper seeks to establish the concept that the analysis of high temporal resolution meteorological data adds value to the investigation of the effect of climatic variability on the prevalence and severity of agricultural pests and diseases. Specifically we attempt to improve disease potential maps of root rots in common beans, based on a combination of inherent susceptibility and the risk of exposure to critical weather events. We achieve this using simulated datasets of daily rainfall to assess the probability of heavy rainfall events at particular times during the cropping season. We then validate these simulated events with observations from meteorological stations in East Africa. We also assess the utility of remotely sensed daily rainfall estimates in near real time for the purposes of updating the risks of these events over large areas and for providing warnings of potential disease outbreaks. We find that simulated rainfall data provide the means to assess risk over large areas, but there are too few datasets of observed rainfall to definitively validate the probabilities of heavy rainfall events generated using rainfall simulations such as those generated by MarkSim. We also find that selected satellite rainfall estimates are unable to predict observed rainfall events with any power, but data from a sufficiently dense network of rain gauges are not available in the region. Despite these problems we show that remotely sensed rainfall estimates may provide a more realistic assessment of rainfall over large areas where rainfall observations are not available, and alternative satellite estimates should be explored.
\end{abstract}

\section{INTRODUGTION}

Pests and diseases are a major cause of low productivity in crops and livestock worldwide (Oerke et al., 1995) and particularly in sub-Saharan Africa where there are few resources to invest in protection in the form of pesticides, vaccines, etc. (Homewood et al., 2006; Otsyula et al., 2004; Williamson et al., 2008).

A number of pest and disease outbreaks are triggered by climatic factors (Table 1). For some biotic stresses the general seasonal conditions are most important while for others the timing of rainfall or dry spells within a season is crucial when they coincide with susceptible periods of plant or animal growth, such as in the case of aflatoxins (Aspergillus spp.) in groundnuts (Arachis hypogaea). Risk management is an integral

łCorresponding author. a.farrow@cgiar.org

Address for correspondence: CIAT-Africa, Kawanda Agricultural Research Institute, Kampala, P.O. Box 6247, Uganda

§Present address. Rwanda Meteorological Service, P.O.Box: 898 Kigali Rwanda

ฯPresent address. Centre for Water Research, University of Western Australia, Perth, Australia 
Table 1. Examples of crop pests and diseases associated with specific climatic conditions.

\begin{tabular}{lll}
\hline Target & \multicolumn{1}{c}{ Pest/disease } & \multicolumn{1}{c}{ Climate favouring outbreak } \\
\hline Cattle & Rift valley fever & Moist conditions \\
Groundnut (Arachis) & Aflatoxin & Dry spell during pod filling \\
Potato (Solanum tuberosum) & Late blight (Phytophthora infestans) & Moist conditions \\
Maize (Zea mays) & Maize streak virus & Moist conditions \\
Cassava (Manihot eculenta) & Cassava mosaic virus & Moist conditions \\
Sorghum (Sorghum bicolor) & Mould/smut (Fusarium moniliforme) & Dryer conditions \\
Sorghum & Charcoal rot (Macrophomina & Soil moisture stress \\
& phaseolina) & \\
Cattle & Sleeping sickness & Rainfall and temperature \\
& (trypanosomiasis) & \\
Common bean (Phaseolus vulgaris) & Root rots (Pythium spp.) & Free water in soil post-germination \\
Chickpea (Cicer arietinum) & Stem rot (Sclerotinia sclerotiorum) & Cool and wet conditions \\
Banana (Musa spp.) & Black sigatoka (Mycosphaerella & High relative humidity and water \\
& fijiensis) & on leaves \\
Pearl millet (Pennisetum glancum) & Smut (Tolyposporium pennicillariae) & Warm temperature, moderate \\
& & humidity and low windspeed \\
Pearl millet & Ergot (Claviceps fusiformis) & Moderate minimum temperatures \\
& & and water on leaves \\
\hline
\end{tabular}

Sources: Ford and Leggate, 1961; Fry and Goodwin, 1997; Haware, 1990; Jésus et al., 2008; Kousik et al., 1988; Morton, 2007; Mouliom Pefora, 1991; Nene, 1979; Reddy and Sulochanamma, 2008; Rogers et al., 1996; Thakur et al., 1991 .

component of coping with the effects of natural hazards (Baez and Mason, 2008) and the use of meteorological data is among the risk management strategies available to producers to help assess the probability of events that foster the transmission or prevalence of pests and diseases. The analysis and monitoring of extreme weather events, and where possible their prediction, can help researchers, extension agents, farmers and pastoralists invest in the most appropriate risk management strategies (Cooper et al., 2008) and prepare for the effects of changes in climates (Garrett et al., 2009).

In this paper we focus on one example of a disease which is triggered by particular climatic conditions. The fungal disease bean root rot complex (Pythium spp., Fusarium solani subsp. phaseoli, Rhizoctonia solani) has a major impact on bean yields throughout its range in Africa (Otsyula, 1994). Each year, the disease affects the livelihoods of millions of people who depend on beans for food security and income (Wortmann et al., 1998).

The impact of the disease varies through time. In some years incidence is relatively low; in others entire crops are wiped out (CIAT, 1992). The distribution and severity of the disease throughout the East African region is related to the intensity of bean cultivation, the human population density, soil properties and rainfall (Otsyula and Buruchara, 2001; Wortmann et al., 1998). The disease varies widely with location; one area may be disease-free while others are hit badly (Buruchara and Rusuku, 1992). This heterogeneity obstructs adaptation of protective practices, because broad remedies become cumbersome and inefficient (Ojiem, 2006). In addition protection 
may penalize yield or quality; resistant or tolerant bean varieties may not be preferred (Otsyula et al., 2003), and seed producers may be unable to respond to demand for resistant varieties (Otsyula et al., 2004). Cultural practices to cope with disease risk respond slowly to variations in actual risk of disease or where causality is poorly understood (Spence, 2003), which may vary significantly during a season depending on growing season rainfall (CIAT, 1992).

Maps showing the importance of root rots were produced in 1998 based on expert knowledge and some modelling of soil, human population and farming system data (Wortmann et al., 1998), but climatic factors were not considered. Root rot infestation requires free water in the root-zone of the soil since the most important pathogen (Pythium spp.) is water-borne (Pieczarka and Abawi, 1978). Research in Rwanda over three growing seasons showed that three-day rainfall totals of at least $50 \mathrm{~mm}$ and up to $130 \mathrm{~mm}$ coincided with plant loss rates of up to $55 \%$ (of susceptible varieties). In the one season where no three-day rainfall events greater than $30 \mathrm{~mm}$ were observed, there were far lower plant losses (CIAT, 1992). The timing of the events was crucial (Abawi et al., 1985) with the period between 17 and 38 days after planting being the most sensitive.

New datasets and tools developed since the creation of the original maps of root rot incidence allow for the more accurate representation of population and land use and for the simulation and analysis of daily weather events (Cooper et al., 2008; Jones et al., 2002).

The objectives of the research presented in this paper are twofold. The first objective is to produce disease potential maps, based on a combination of inherent susceptibility and the risk of exposure to critical weather events within a general vulnerability framework (Alwang et al., 2001). Susceptibility to root rots is determined by up to date and high resolution spatial datasets of human population density and the intensity of bean cultivation in bean producing areas of East Africa. Risk of exposure maps show the likelihood of experiencing rainfall events during specific periods of the growing season in susceptible areas. The output of this objective allows accurate targeting of resistant cultivars or other husbandry techniques throughout the region, and quantitative insights from new models showing current and likely future incidence.

The second objective is to assess the possibility of within-season monitoring of rainfall events over large areas using satellite-based rainfall estimating instruments. This would offer a flexible basis on which to improve predictive models through the continued acquisition of rainfall data especially when combined with information on the severity of root rots in any particular area.

MATERIALS AND METHODS

This study concentrated on the East African countries most affected by root rots in beans: Rwanda, Burundi, the Democratic Republic of the Congo, Uganda, Tanzania and Kenya. Further targeting was achieved by the development of a new map of areas 
susceptible to root rots in beans based on population density and the intensity of bean cultivation.

The probability of experiencing heavy rainfall events in the early growing season was assessed at key locations within the susceptible areas using daily rainfall observations simulated by the MarkSim (Jones et al., 2002) software and analysed for high intensity events using the InStat+ software (University of Reading, 2008). (For further details see Supplementary Online Appendix at http://journals.cambridge.org/EAG). MarkSim has been applied in the region for crop simulation modelling (Jones and Thornton, 2000) but has not been used for the analysis of disease risk. The likelihood of simulated high rainfall events were then compared with rainfall observations from meteorological stations in Kenya, Uganda and Rwanda.

Finally satellite measurements were assessed for use in further validating the risk surfaces and for their suitability for in-season monitoring of rainfall events.

\section{Assessing the risk of root rots in East African bean producing areas}

Areas susceptible to bean root rots. The association between root rot severity and human population density, intensity of cultivation and soil properties were based on a model derived from data collected for the atlas of common bean production in Africa (Wortmann, et al., 1998). Bean producing areas have not been captured since 1998 and we assume that production areas have not changed markedly in East Africa relative to the late 1990 s.

We have updated the original root rot map using more recent data on population density - the Gridded Population of the World Version 3 (CIESIN, 2005) - and the SAGE Agricultural Lands map for cropping intensity, based on the percentage of a 5 arc minute cell that is cropped (Ramankutty et al., 2008).Threshold values for crop intensity and human population density were used to further restrict the area of analysis. Values of $40 \%$ crop intensity and 200 persons per $\mathrm{km}^{2}$ were chosen. These were then combined using simple map algebra in ArcMap (ESRI) software to create a map showing areas with both high human population density and high bean crop intensity (Figure 1).

Risk of exposure to heavy rainfall events. Rainfall during the first few weeks of plant development has a spatial component but is difficult to capture using conventional maps of annual or monthly rainfall totals. Averages mask the variability of rainfall within the year or month as well as the variation between years. To obtain a better indication of risk one must analyse daily weather data and specifically daily rainfall observations during the critical period immediately after germination.

Observations from meteorological stations are often not available, incomplete or in non-susceptible locations. Sample locations were selected in areas susceptible to root rots in each bean producing area (Figure 2) and simulations of daily weather were generated for 99 years using the MarkSim Software. For each of the 24 locations the normal planting dates were identified using expert knowledge (Table 2) (personal communications, Rubyogo, December 2005, Chirwa, December 2005). 
The daily rainfall data were exported from MarkSim and imported into the Instat+ software (University of Reading, 2008). The Instat+ software has analysis capabilities designed for climatic data, specifically the identification of specific events. The rules for assessing risk of root rot were more complex than traditional rainy events but a combination of these events allowed the calculation of risk. The first step was to define a monitoring period that started approximately one month before the normal planting dates and identify the start of rains; a figure of $20 \mathrm{~mm}$ over two days was used for the onset of the rainy season. The next step was to determine the absence or presence of events with over $50 \mathrm{~mm}$ over two days in the period between day 17 and day 38 (after the onset of rains); a more severe test - $100 \mathrm{~mm}$ over three days - was also used. Since all locations had bimodal rainfall patterns the test was applied to both rainy seasons in the calendar year and the number of seasons where the rainfall events were experienced was recorded (Table 2). MarkSim successfully simulated daily rainfall in all but one of the locations for which the software had no climate data.

These frequencies were used to produce maps of risk over large areas when the point data were interpolated to produce a risk surface (Figure 3). The frequency values were interpolated in the ArcGIS software for all susceptible areas using inverse distance weighting with a distance decay power value of 2 and using 12 nearest neighbours.

\section{Validation of exposure risk}

Little information has been collected on the frequency of root rot incidence in beans across East Africa. Data collected in Rwanda in the early 1990s (Buruchara and Rusuku, 1992) concentrated on yield loss rather than frequency: reports from this period showed that the severity of losses was greater in some regions in Rwanda than others, which might be due to differences in rainfall patterns. However, differences between neighbouring fields were also observed, which serves to remind that causality of incidence is complex, with soil fertility being another important factor.

Comparison between observed and simulated heavy rainfall events. Observed daily rainfall data were made available for this study in four locations in East Africa: Katumani in Eastern Province in Kenya, Kabete in Central Province in Kenya, Namulonge in Central Uganda and Kigali in Rwanda (Figure 2). The longest time series available was for Katumani, where 41 years of continuous observations between 1961 and 2001 were recorded. Daily rainfall amounts were observed for 30 years in Kabete, 32 years in Namulonge and for 11 years at Kigali.

The observations were imported into the Instat+ software and the same process followed as described above (Risk of exposure to heavy rainfall events) to determine the number of heavy rainfall events during the post-germination period. Additional simulations were generated using MarkSim at the same locations as the meteorological stations. At such sites MarkSim can use observed climatic normals for rainfall, or the values built in to the software. We decided to use those built-in, to match the simulations at sites where there is no station (cf. Hartkamp et al., 2003). 
Table 2. Sample locations ${ }^{\dagger}$ with number of years with heavy rainfall events (simulated by MarkSim) per 99 years.

\begin{tabular}{|c|c|c|c|c|c|c|c|c|c|c|c|c|c|}
\hline \multirow[b]{2}{*}{$\begin{array}{c}\text { MarkSim } \\
\text { ID }\end{array}$} & \multirow[b]{2}{*}{ Country } & \multirow[b]{2}{*}{ Latitude } & \multirow[b]{2}{*}{ Longitude } & \multicolumn{4}{|c|}{ Main season } & \multicolumn{4}{|c|}{ Other season } & \multicolumn{2}{|c|}{ Average } \\
\hline & & & & Start & $\begin{array}{l}\text { Day number } \\
\text { for monitoring } \\
\text { start of season }\end{array}$ & $\begin{array}{c}50 \mathrm{~mm} \\
\text { over } 2 \\
\text { days }\end{array}$ & $\begin{array}{c}100 \mathrm{~mm} \\
\text { over } 3 \\
\text { days }\end{array}$ & Start & $\begin{array}{l}\text { Day number } \\
\text { for monitoring } \\
\text { start of season }\end{array}$ & $\begin{array}{c}50 \mathrm{~mm} \\
\text { over } 2 \\
\text { days }\end{array}$ & $\begin{array}{c}100 \mathrm{~mm} \\
\text { over } 3 \\
\text { days }\end{array}$ & $\begin{array}{c}50 \mathrm{~mm} \\
\text { over } 2 \\
\text { days }\end{array}$ & $\begin{array}{c}100 \mathrm{~mm} \\
\text { over } 3 \\
\text { days }\end{array}$ \\
\hline (a) & Central Kenya & -1.168 & 37.949 & March & 32 & 36 & 22 & September & 213 & 53 & 34 & 45 & 28 \\
\hline (b) & Central Kenya & -0.514 & 37.069 & March & 32 & 36 & 17 & September & 213 & 24 & 6 & 30 & 12 \\
\hline (c) & Tanzania & -3.310 & 37.485 & March & 32 & 37 & 9 & September & 213 & 9 & 1 & 23 & 5 \\
\hline (d) & Western Kenya & 0.640 & 35.783 & Feb-April & 32 & 20 & 4 & Aug-Oct & 213 & 15 & 0 & 18 & 2 \\
\hline (e) & Uganda & 0.490 & 30.223 & March & 32 & 36 & 10 & September & 213 & 39 & 5 & 38 & 8 \\
\hline (f) & Uganda & 1.585 & 33.865 & March & 32 & 1 & 0 & September & 213 & 0 & 0 & 1 & 0 \\
\hline (g) & Uganda & 3.049 & 30.865 & March & 32 & 37 & 7 & September & 213 & 48 & 13 & 43 & 10 \\
\hline (h) & Burundi & -4.130 & 30.032 & March-April & 60 & 67 & 17 & Sept-Oct & 244 & 36 & 12 & 52 & 15 \\
\hline (i) & Rwanda & -1.992 & 30.470 & March-April & 60 & 38 & 6 & Sept-Oct & 244 & 32 & 5 & 35 & 6 \\
\hline (j) & Burundi & -2.522 & 30.024 & March-April & 60 & No data & No data & Sept-Oct & 244 & No data & No data & & \\
\hline (k) & Burundi & -3.397 & 29.671 & March-April & 60 & 29 & 2 & Sept-Oct & 244 & 17 & 3 & 23 & 3 \\
\hline (l) & Rwanda & -2.631 & 28.981 & March-April & 60 & 20 & 0 & Sept-Oct & 244 & 18 & 1 & 19 & 1 \\
\hline (m) & Burundi & -2.884 & 29.199 & March-April & 60 & 33 & 4 & Sept-Oct & 244 & 27 & 8 & 30 & 6 \\
\hline (n) & Burundi & -3.616 & 30.007 & March-April & 60 & 45 & 8 & Sept-Oct & 244 & 23 & 2 & 34 & 5 \\
\hline (o) & Rwanda & -1.575 & 29.561 & March-April & 60 & 28 & 3 & Sept-Oct & 244 & 14 & 1 & 21 & 2 \\
\hline (p) & Rwanda & -1.676 & 30.108 & March-April & 60 & 31 & 3 & Sept-Oct & 244 & 16 & 1 & 24 & 2 \\
\hline (q) & Uganda & -1.214 & 30.041 & March & 32 & 19 & 4 & September & 213 & 19 & 3 & 19 & 4 \\
\hline$(\mathrm{r})$ & Uganda & -0.574 & 30.361 & March & 32 & 22 & 0 & September & 213 & 14 & 1 & 18 & 1 \\
\hline (s) & Western Kenya & -0.574 & 34.576 & Feb-April & 32 & 34 & 6 & Aug-Oct & 213 & 29 & 8 & 32 & 7 \\
\hline$(\mathrm{t})$ & Western Kenya & -0.524 & 35.165 & Feb-April & 32 & 37 & 8 & Aug-Oct & 213 & 23 & 2 & 30 & 5 \\
\hline (u) & Western Kenya & 0.149 & 34.669 & Feb-April & 32 & 41 & 7 & Aug-Oct & 213 & 44 & 16 & 43 & 12 \\
\hline (v) & Western Kenya & 0.157 & 34.282 & Feb-April & 32 & 29 & 4 & Aug-Oct & 213 & 45 & 3 & 37 & 4 \\
\hline$(w)$ & Uganda & 0.637 & 33.087 & March & 32 & 28 & 2 & September & 213 & 29 & 2 & 29 & 2 \\
\hline$(\mathrm{x})$ & Uganda & -0.229 & 31.656 & March & 32 & 24 & 7 & September & 213 & 28 & 0 & 26 & 4 \\
\hline
\end{tabular}

${ }^{\dagger}$ Sample locations are indicated on Figure 2. 
Table 3. Rwanda Meteorological Service stations with available rainfall data.

\begin{tabular}{lllc}
\hline Station & Start date & Finish date & $\begin{array}{c}\text { Years with at least } \\
\text { 1 month missing }\end{array}$ \\
\hline Kigali & January 1998 & December 2008 & 0 \\
Gisenyi & March 2002 & December 2008 & 0 \\
Gikongoro & January 1998 & December 2008 & 7 \\
Byumba & January 2007 & December 2008 & 0 \\
Kamembe & January 2004 & May 2009 & 0 \\
\hline
\end{tabular}

\section{TRMM validation of risk surfaces}

Alternative sources of 'observed' daily rainfall are satellite-based instruments that measure the characteristics of clouds to estimate rainfall on the ground. One of these sources - the Tropical Rainfall Measuring Mission (TRMM) - is assessed here as an alternative to ground measuring stations to validate the assessment of heavy rainfall events and to investigate the potential of remotely sensed rainfall estimates for in-season monitoring and early warning of root rot outbreaks.

The TRMM has five principal instruments: a precipitation radar, a microwave imager, a visible and infra-red scanner, a cloud and earth radiant energy scanner and a lightning imaging scanner (NASA, 2006). The principal dataset used in this section is the daily rainfall estimates dataset derived from the 3B42 v6 algorithm which combines data from TRMM microwave and infra-red instruments (Huffman et al., 2007). The data are available from 1998 and have a spatial resolution of $0.25^{\circ} \times$ $0.25^{\circ}$ between latitudes of $50^{\circ} \mathrm{S}$ and $50^{\circ} \mathrm{N}$.

Given the relatively small number of years that TRMM has been providing observations the source is not suitable for validating the probability of heavy rainfall events in a season (using MarkSim simulated daily rainfall). Instead we assessed the quality of the TRMM daily rainfall data using rainfall observations from stations in just one country in East Africa - Rwanda.

Observed rainfall data from five stations of the Rwandan Meteorological Service (RMS) were available and TRMM daily rainfall estimates data were extracted for the period 1998-2008 for grid cells that coincided with the RMS stations. For the purposes of monitoring conditions conducive to root rots in beans the most appropriate indicator for validating the TRMM estimates was a three-day running rainfall total during the growing seasons. Rainfall records for Kigali airport meteorological station were complete for the period 1998-2008 while there were gaps for the stations at Gisenyi and Gikongoro and serious gaps for Byumba (Table 3). Data for Kamembe airport had yet to be verified so were not analysed.

We focused the analysis on the start of the growing seasons, which are between February and April inclusive and between September and November inclusive. Different rainfall amounts were chosen ranging from $100 \mathrm{~mm}$ over three days (which is rarely encountered) to $25 \mathrm{~mm}$ over three days which was almost always exceeded. 
Table 4. Percentage of bean growing areas in East and Central Africa susceptible to root rots.

\begin{tabular}{llll}
\hline Country & $\begin{array}{c}\text { Total bean growing } \\
\text { areas (ha) }\end{array}$ & Susceptible (ha) & $\%$ \\
\hline Burundi & 2648000 & 841000 & 32 \\
DRC & 17304000 & 32000 & 0 \\
Kenya & 13655000 & 1248000 & 9 \\
Rwanda & 2197000 & 929000 & 42 \\
Tanzania & 10825000 & 45000 & 0 \\
Uganda & 16310000 & 2136000 & 13 \\
\hline
\end{tabular}

DRC: Democratic Republic of the Congo.

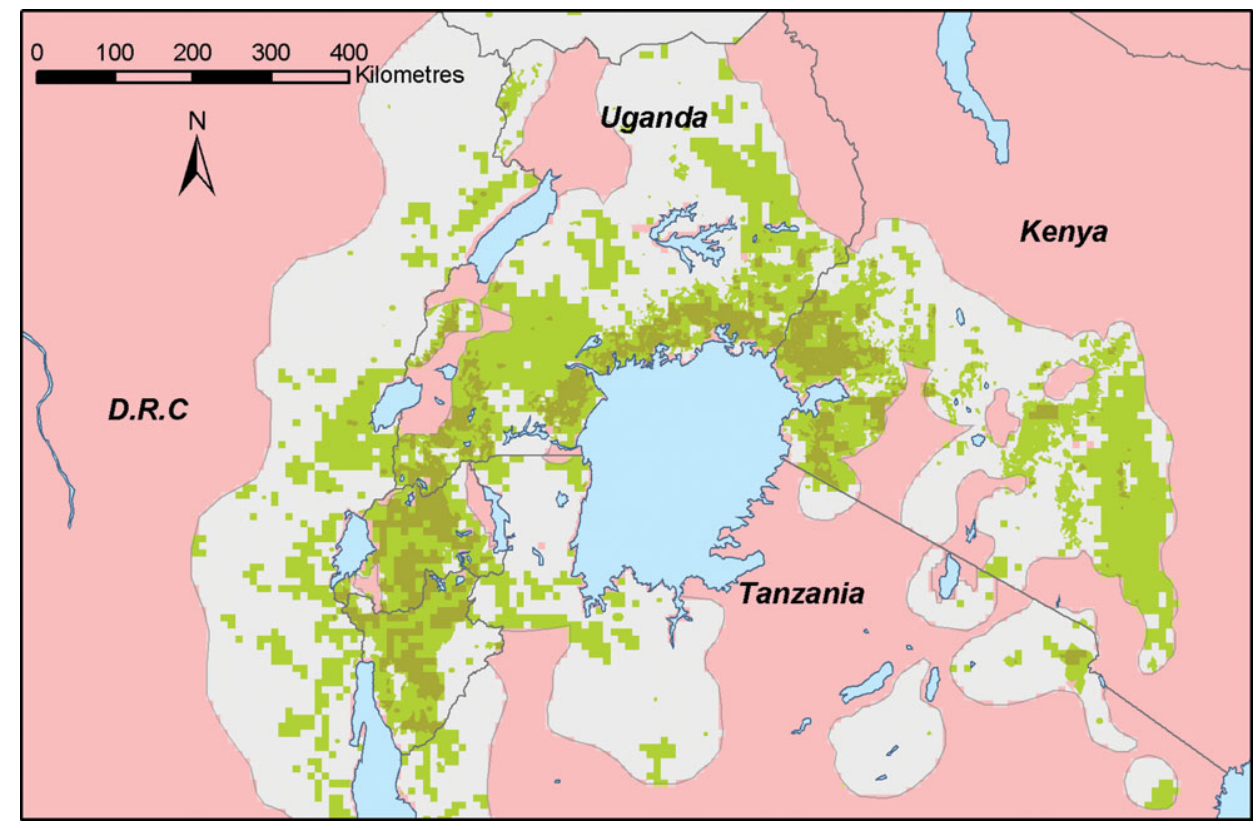

Figure 1. Combination of crop intensity and population density to focus on bean areas susceptible to root rots. Pink signifies non-bean areas; grey areas excluded according to two criteria; light green areas are excluded by one criterion; dark green areas satisfy both criteria. DRC: Democratic Republic of Congo.

\section{RESULTS}

Risk of root rots in East African bean producing areas

Areas susceptible to bean root rots. The areas susceptible to bean root rots are concentrated in two main regions: (a) the highlands of Rwanda, Burundi and South western Uganda, and (b) the northern shore of lake Victoria and the highlands of western Kenya. There are other smaller areas scattered in Central and Eastern provinces of Kenya and in the Kilimanjaro massif in north-eastern Tanzania. In terms of the proportion of the bean areas in each country affected the most susceptible was Rwanda while the least susceptible was the Democratic Republic of the Congo (Table 4). 


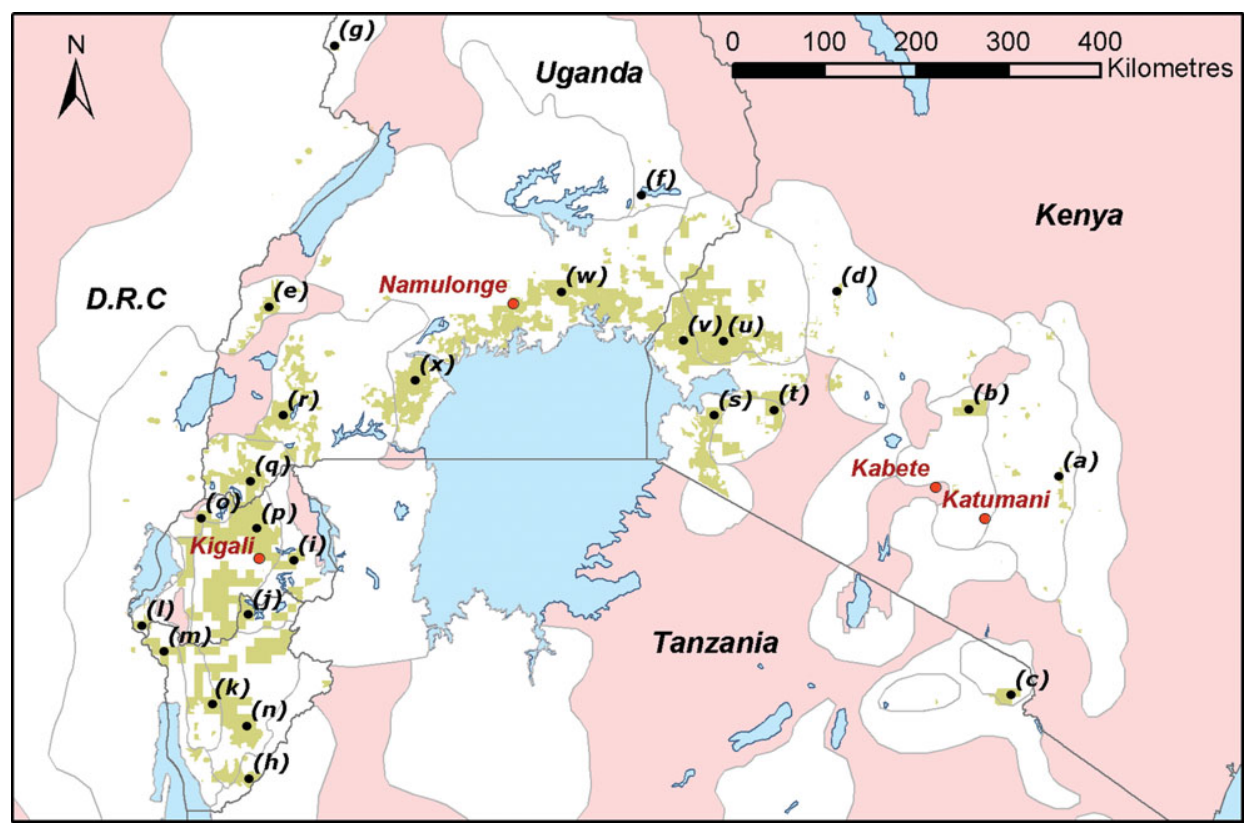

Figure 2. Locations of MarkSim simulations in bean areas susceptible to root rots. Meteorological stations shown as red circle, MarkSim simulation locations shown as black circles (sample locations given in Table 2 are identified by letters in parentheses). Pink signifies non-bean areas; white areas excluded according to one or two criteria; olive green areas satisfy both criteria. DRC: Democratic Republic of Congo.

Risk of exposure to heavy rainfall events. The locations with the highest risk of heavy rainfall events during the period immediately after germination are in southern Burundi, a small area in northwest Uganda, the Kakamega area of western Kenya and in Kitui in Eastern Province of Kenya. Areas with lower risk are in western Rwanda and southwest Uganda. Despite a range of environments from humid to semi-arid the range of probabilities is not large, and surprisingly some of the locations with the highest probabilities of heavy rainfall events (such as eastern Kenya and eastern Rwanda) do not have high seasonal rainfall totals.

\section{Validation of exposure risk}

Comparison between observed and simulated heavy rainfall events. The differences between the numbers of seasons with heavy rainfall events in the susceptible period according to observed and simulated daily rainfall were not large and did not show consistency between locations or seasons (Table 5). For instance at Katumani there were more 'risky' seasons according to the simulated data using MarkSim than with the observed data; this is also true in the case of Kigali. In contrast for Kabete there were more risky seasons using observed data than the simulated daily data for the main season, but this was reversed in the second season - a similar pattern to the comparison at Namulonge. 


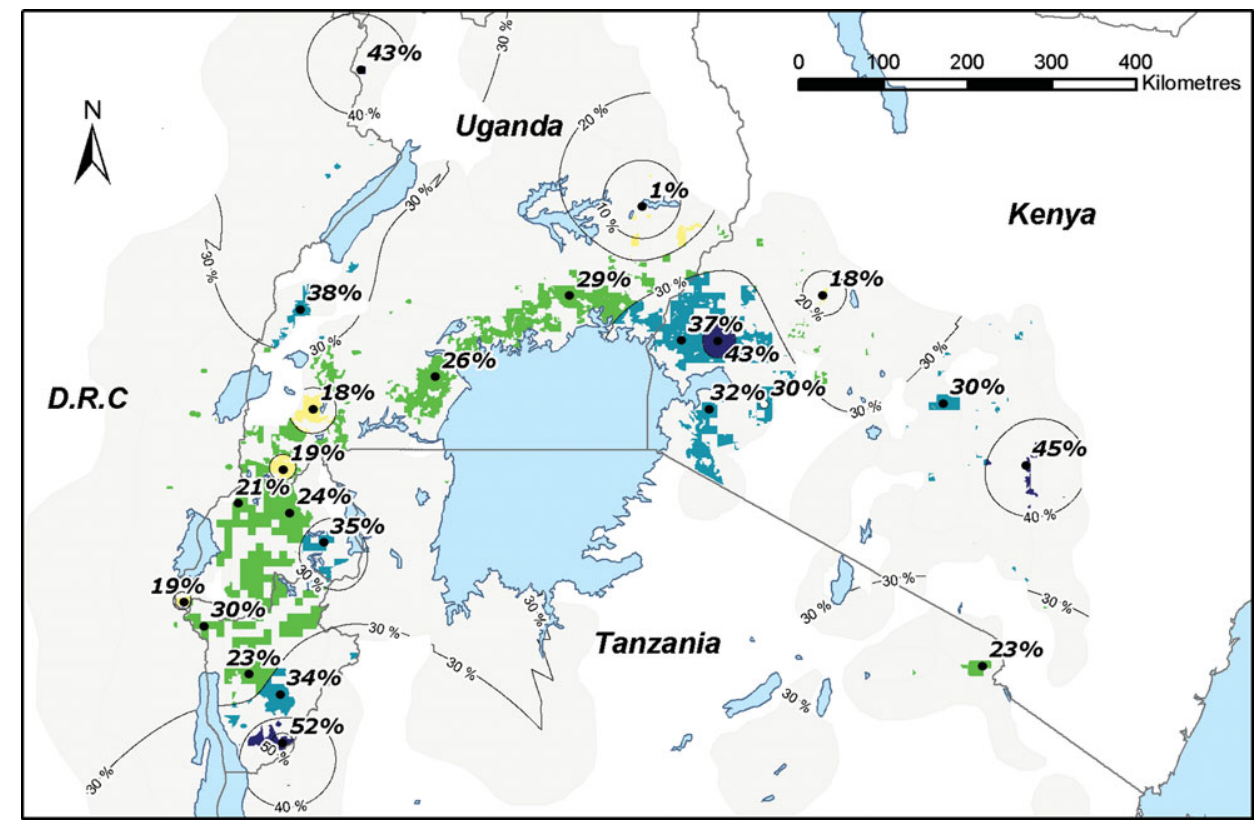

Figure 3. Probability of rainfall events exceeding $50 \mathrm{~mm}$ in 3 week post-germination susceptible period. MarkSim simulation locations shown as black circles. White $=$ non-bean areas; grey = excluded according to one or two criteria; yellow $=<20 \%$; green $=20-30 \%$; blue $=30-40 \%$; dark blue $=>40 \%$. DRC: Democratic Republic of Congo.

The comparison between the observed and simulated rainfall events is between two binomial distributions, where each season either experiences a heavy rainfall event or not. Our hypothesis was that the probability of the heavy rainfall event was the same for each distribution. This hypothesis was only rejected at the 5\% confidence level for the second season at Katumani (Table 5).

\section{TRMM validation of risk surfaces}

Results are organized for each of the four stations in Rwanda: Kigali, Gisenyi, Gikongoro and Byumba. Greatest attention was paid to the results obtained from Kigali since it had the longest and best quality weather data available.

A plot of the three-day running totals (calculated daily) from the TRMM and observed rainfall data at Kigali showed a lack of a clear relationship between the totals from TRMM and from meteorological stations $\left(R^{2}=0.204\right)$. The TRMM data give slightly higher three-day totals although there are more extreme rainfall events (e.g. $>$ $100 \mathrm{~mm}$ ) in the observed dataset.

Graphs were also produced for individual years, with a range of predictive capacities of the observed cumulative rainfall using just TRMM estimates between $R^{2}=0.05$ in 2008 and 0.64 in 2002.

These predictive models investigate the relationship between the TRMM wet events and the observed wet events on a daily basis, but they do not show the differences 
Table 5. Comparison of number of seasons with heavy rainfall events using observed and simulated (MarkSim) daily rainfall data for four locations in East Africa.

\begin{tabular}{|c|c|c|c|c|c|}
\hline & \multirow[b]{2}{*}{ No. of years } & \multicolumn{2}{|c|}{$\%$ of main seasons with } & \multicolumn{2}{|c|}{$\%$ of other seasons with } \\
\hline & & $\begin{array}{c}50 \mathrm{~mm} \text { over } \\
2 \text { days }\end{array}$ & $\begin{array}{c}100 \mathrm{~mm} \\
\text { over } 3 \text { days }\end{array}$ & $\begin{array}{c}50 \mathrm{~mm} \text { over } \\
2 \text { days }\end{array}$ & $\begin{array}{c}100 \mathrm{~mm} \\
\text { over } 3 \text { days }\end{array}$ \\
\hline \multicolumn{6}{|c|}{ Katumani, Eastern Kenya (a) } \\
\hline Observed & 41 & 22 & 5 & 27 & 5 \\
\hline Simulated & 99 & 35 & 13 & 45 & 14 \\
\hline$p$-value** & & 0.12 & 0.15 & 0.04 & 0.12 \\
\hline \multicolumn{6}{|c|}{ Kabete, Central Kenya (b) } \\
\hline Observed & 30 & 47 & 20 & 17 & 3 \\
\hline Simulated & 99 & 39 & 11 & 22 & 7 \\
\hline$p$-value** & & 0.48 & 0.21 & 0.51 & 0.46 \\
\hline \multicolumn{6}{|c|}{ Namulonge, Uganda (c) } \\
\hline Observed $^{\dagger}$ & 32 & 19 & 3 & 19 & 3 \\
\hline Simulated & 99 & 25 & 7 & 13 & 1 \\
\hline$p$-value** & & 0.45 & 0.42 & 0.43 & 0.40 \\
\hline \multicolumn{6}{|c|}{ Kigali, Rwanda (d) } \\
\hline Observed & 11 & 36 & 0 & 18 & 0 \\
\hline Simulated & 99 & 36 & 6 & 22 & 5 \\
\hline$p$-value** & & 1.00 & 0.40 & 0.76 & 0.45 \\
\hline
\end{tabular}

Main season: $\mathrm{a}, \mathrm{b}, \mathrm{c}=$ March; $\mathrm{d}=$ Mid-March-early April. Other season: $\mathrm{a}, \mathrm{b}, \mathrm{c}=$ September; $\mathrm{d}=$ Mid-September-early October.

${ }^{\dagger} 1991$ main season observations not available but other season (September-November) observations were available.

${ }^{* *}$ The $p$-value is the significance level for the test that the two proportions are equal.

in the experience of at least one heavy rainfall event during the growing season. An alternative approach is to analyse threshold values of three-day rainfall events in any particular growing season (i.e. the same as that used to examine the rainy events in the analysis of the TRMM data conducted previously by the authors).

The summary of the presence of different events (Table 6) shows that the amount of trigger events is broadly similar between the observed and the TRMM rainfall data. When the individual years are analysed separately the coincidence between the two datasets is not as strong, especially for the $50 \mathrm{~mm}$ trigger rainfall events where the trigger rainfall amount is estimated correctly in only $55 \%$ of the threemonthly periods. Observed data for Byumba station were only available for 2007 and 2008 limiting the power of the comparison with the TRMM data. More data were available for the station at Gisenyi but the number of matches is low compared to Kigali, with the number of false negatives very large. There are gaps in the observed rainfall data for Gikongoro, with only 2008, 2003, 1999 and all but the first week of 1998 complete. All the other years have some months missing and only the second season in 2004 was complete. As with Gisenyi the number of false absences in Gikongoro is far greater than the false presences of heavy rainfall events. The seasonal totals of the observed rainfall were also greater than the TRMM estimates. 
Table 6. Comparison of total number of seasons with rainfall events and season by season comparison of absence/presence of events 1998-2008 at Kigali.

\begin{tabular}{|c|c|c|c|c|c|c|c|}
\hline \multirow[b]{2}{*}{ Rainfall event } & \multicolumn{2}{|c|}{ No. of seasons $(n=22)$} & \multicolumn{2}{|c|}{ Percentage of seasons } & \multirow[b]{2}{*}{ Match } & \multirow[b]{2}{*}{ False presence } & \multirow[b]{2}{*}{ False absence } \\
\hline & TRMM & Observed & TRMM & Observed & & & \\
\hline $100 \mathrm{~mm}$ in 3 days & 0 & 0 & 0 & 0 & 22 & 0 & 0 \\
\hline $50 \mathrm{~mm}$ in 3 days & 12 & 12 & 55 & 55 & 12 & 5 & 5 \\
\hline $40 \mathrm{~mm}$ in 3 days & 16 & 17 & 73 & 77 & 17 & 2 & 3 \\
\hline $35 \mathrm{~mm}$ in 3 days & 17 & 19 & 77 & 87 & 16 & 2 & 4 \\
\hline $30 \mathrm{~mm}$ in 3 days & 19 & 21 & 86 & 95 & 18 & 1 & 3 \\
\hline $25 \mathrm{~mm}$ in 3 days & 20 & 21 & 91 & 95 & 19 & 1 & 2 \\
\hline
\end{tabular}

The TRMM therefore provides little power for predicting these three-day rainfall events at the meteorological stations.

\section{DISCUSSION}

The research presented in this paper outlines a new use of simulations of daily rainfall, and specifically a new use of the MarkSim software. The value of these simulated data is increased when they are combined with climatic statistical and spatial tools, and they demonstrate the use of such data for targeting both strategic research and specific interventions to tackle crop pests and diseases. This research is particularly pertinent in the face of potential changes in rainfall patterns over the coming decades (van de Steeg et al., 2009).

Although no 'ground truthing' was possible in this study, the map of the probability of root rots appears consistent with the previous map of root rot severity (Wortmann et al., 1998). Nevertheless the revised map can be improved by using MarkSim simulations of daily rainfall over all the susceptible areas rather than interpolating between the 24 locations that were sampled in this study as well as alternative interpolation methods such as kriging (e.g. Grimes et al., 1999). This will require a more automated procedure for the identification of heavy rainfall events. The variation in risk of heavy rainfall events shown here does not show a simple correlation with annual or seasonal rainfall averages and thus provides a novel tool for targeting the promotion of root rot resistant bean varieties and other cultural practices for modifying the soil structure and improving soil fertility. This tool can be modified for other pests and diseases and for other crops or agricultural technologies. Nevertheless the research here has shown that the spatial scale at which pests and diseases are manifest will limit the usefulness of the tool since MarkSim currently has a spatial resolution of $18 \mathrm{~km}$. Differences in root rot incidence and severity within and between plots are due mainly to the build up of pathogens in the soil - which is linked to the soil fertility status and the cultivation history of a particular plot - and whether a variety is resistant to root rots.

Plant breeding for resistance to root rots has been ongoing within the Pan African Bean Research Alliance, but there is often a trade-off between traits. In addition the resources destined for crop improvement need to be targeted to those areas where 
particular constraints are most severe, both now and in the future. It is currently difficult to link the rainfall event probability map to actual incidence and severity of root rots in the region, due to a lack of routine monitoring of outbreaks of the disease. If monitoring were carried out it would allow for better calibration of the model and also an even better understanding of the risk. This understanding will be vital for modelling the incidence of root rots in beans under future climates, especially for areas where the disease is currently uncommon.

The validation of the MarkSim heavy rainfall events with rainfall observations from four stations shows that the differences between the two sources were in most cases not statistically significant. Access to a longer series of observed rainfall data would be needed to comprehensively assess the simulated dataset in those areas where the differences between the observed and simulated datasets are large. We are unable to reject the hypothesis that the distributions of risky rainfall events are the same between the observed and simulated daily rainfall datasets. We therefore tentatively conclude that simulated daily rainfall can be used for producing these kinds of risk assessments, but that the validation could be improved by increasing the sample of meteorological stations.

The rainfall amounts over the two and three day time steps used in this analysis are derived from a combination of the probability of rain days as well as the amount of rain falling on a rainy day. The first of these is derived from the analysis of the daily data for the meteorological station used to define the climate type, while the amounts of rainfall depend on the monthly mean rainfall values. Within MarkSim there is the possibility of updating the monthly mean rainfall amounts for specific locations and further research could consider the use of summaries of observed data (climate normals) instead of the interpolated means which are in the MarkSim database. The thresholds for heavy rainfall events are based on trials carried out in Rwanda and the results of the risk model are dependent on the rainfall threshold as well as the planting date. Further research should therefore assess the sensitivity of the model to both of these factors as well as the size of rainfall events simulated by the MarkSim software (e.g. Dixit et al., 2011). Specifically research is required on the effect of the gamma curves which are an essential characteristic of each type of climate within MarkSim and which define the probabilities of rainfall events.

The biggest problem for the comparison is the relatively short duration of the observed rainfall records, especially in Kigali which showed the largest differences between the two datasets. The other problem is the very small number of cases in the analysis which was restricted due to the lack of meteorological stations with available observed daily rainfall. Access to a larger set of meteorological observations would allow a better assessment of the relationship.

Our study of four stations in Rwanda shows that rainfall estimates from TRMM satellite instruments are poor predictors of rainfall observations, coinciding with the findings of Dinku et al. (2008). The most complete set of rainfall observations were available for the Kigali Airport station. Of the six different trigger values the worst comparison was the $50 \mathrm{~mm}$ value, which was incorrectly estimated for 10 of the 22 seasons - either positively estimated when there was no event observed 
or not estimated when the ground station recorded the event. As the trigger value decreased, the number of seasons when the value was estimated also increased, which is not surprising due to the frequent occurrence of these less intense rainfall events.

Comparisons at the other stations were less revealing because the numbers of complete seasons of observed rainfall were fewer than at Kigali. Both the stations in Gikongoro and Gisenyi were at the edge of the $25 \mathrm{~km} \times 25 \mathrm{~km}$ TRMM cell, and given the small size of tropical thunderstorms it is possible that rainfall associated with cloud recorded by the TRMM sensor was not recorded at the meteorological station. Indeed, given the large decay in correlation of rainfall over relatively small distances in the tropics (Lebel et al., 1992), especially over short periods, the utility of a single rain gauge to represent a large area (such as those covered by TRMM pixels) is limited, and the TRMM may give a better estimate of areal rainfall. While the spatial variation in rainfall has been shown over different time periods (Grimes and PardoIgúzquiza, 2010) there is no research on the spatial variation of these heavy rainfall events over short distances, such as could be used to explain the differences between the TRMM areal estimates and the meteorological stations. The AGRHYMET cluster of rainfall gauges (Lebel et al., 1992) or the rain gauges managed by the Ethiopian National Meteorological Agency (Grimes and Pardo-Igúzquiza, 2010) offer such an opportunity to study the local differences in the frequency of heavy rainfall events.

TRMM rainfall data are particularly suited to in-season rainfall monitoring due to the short time between data capture and publication. Typically the data are available the next day when using the TRMM Online Visualization and Analysis System (TOVAS) (http://disc2.nascom.nasa.gov/Giovanni/tovas/). The time period can be set so that cumulative seasonal totals are displayed (Figure 4) or for shorter periods to monitor within season events. These values would still need to be validated using observations although the time between observation, verification and publication would need to be improved. Alternative rainfall estimates from satellite exist, such as NASA's Prediction of World Energy Resources (http://earthwww.larc.nasa.gov/power/), but this has a considerable delay between capture and publishing and is thus currently not suited to in-season monitoring of rainfall. Other rainfall products estimated using satellite instruments include the Tropical Applications of Meteorological Satellites (TAMSAT) method applied to thermal infrared imagery from the Meteosat platform (Thorne et al., 2001). The algorithm used in the TAMSAT method is locally calibrated and has performed well in Africa in comparison with more complex algorithms like those used to produce the TRMM rainfall estimates (Teo and Grimes, 2007). The TAMSAT group provides routine products at 10-day, monthly and seasonal timescales; the decadal and monthly products are available from the EUMETSAT portal. The TAMSAT estimates thus offer some promise for in-season monitoring for root rots but would imply access to daily rainfall estimates.

To conclude, in this paper we have shown the value of long-term meteorological rainfall observations for assessing the risk of outbreaks of pests and diseases. We have 


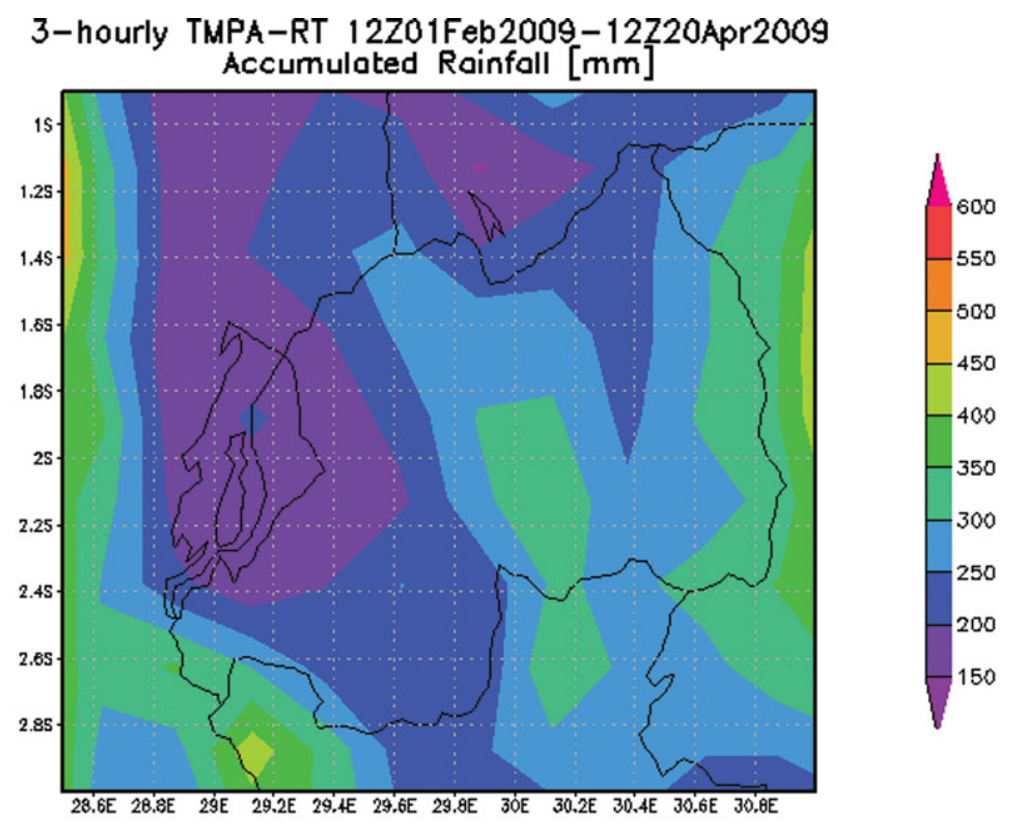

GrADS CQLA/GES

Generated by NASA'E Giovanni (giovanni.gefe.naga.gov)

2009-04-21-09:08

Figure 4. TRMM rainfall total for Rwanda: February-April 2009. The images and data used in this study were acquired using the GES-DISC Interactive Online Visualization ANd aNalysis Infrastructure (Giovanni) as part of the NASA's Goddard Earth Sciences Data and Information Services Center.

also shown that where data are sparse simulations may be are able to provide an acceptable alternative. More rainfall observations from meteorological stations are needed to check the validity of the results from the simulated data and hence to improve the confidence in the results from the simulations. The methods used have shown that these data enable maps of areas susceptible to root rot in beans to be produced, by showing the long-term probability of heavy rainfall events during a critical period after germination. These, in turn, can help assess long-term risks or can be used for early warning within a particular season.

Acknowledgements. The authors would like to acknowledge the African Development Bank who provided funds through the Association for Strengthening Agricultural Research in East and Central Africa (ASARECA) to support the project 'Managing Uncertainty: Innovation systems for coping with climate variability and change' which were used, in part to support this study. The authors are also grateful to the Swiss Agency for Development and Cooperation (SDC) and the Canadian International Development Agency (CIDA) for continuing to support the Pan African Bean Research Alliance (PABRA), which provided additional support to this study. We offer our thanks for the comments and advice of two reviewers which greatly improved the manuscript, and for the commitment and enthusiasm of Peter Cooper. 


\section{REFERENGES}

Abawi, G. S., Crosier, D. C. and Cobb, A. C. (1985). Root rot of snap beans in New York. New York's Food and Life Sciences Bulletin 110: 2-7.

Alwang, J., Siegel, P. B. and Jorgensen, S. L. (2001). Vulnerability: A view from different disciplines. Social Protection Discussion Paper Series No. 0115, World Bank, Washington, DC.

Baez, J. E. and Mason, A. (2008). Dealing with Climate Change: Household Risk Management and Adaptation in Latin America. SSRN eLibrary. Available at http://ssrn.com/paper=1320666 [Accessed 15 November 2010].

Buruchara, R. A., and Rusuku, G. (1992). Root rots research in the Great Lakes Region, in Proceedings of the Pan-Africa Bean Pathology Working Group Meeting. Centro Internacional de Agricultura Tropical, Thika, Kenya, 26 th $-30^{\text {th }}$ May 1992.

CIESIN (Center for International Earth Science Information Network). (2005). Gridded Population of the World Version 3 (GPWv3): Population Density Grids. Palisades, NY: Socioeconomic Data and Applications Center (SEDAC), Columbia University. Available at http://sedac.ciesin.columbia.edu/gpw. [Accessed 17/03/2006].

CIAT (1992). Pathology in Africa. In Bean Programme Annual Report. Cali, Colombia, Centro Internacional de Agricultura Tropical. December 1992.

Cooper, P. J. M., Dimes, J., Rao, K. P. C., Shapiro, B., Shiferaw, B. and Twomlow, S., (2008). Coping better with current climatic variability in the rain-fed farming systems of sub-Saharan Africa: An essential first step in adapting to future climate change? Agriculture, Ecosystems \& Environment 126: 24-35.

Dinku, T., Chidzambwa, S., Ceccato, P., Connor, S. J. and Ropelewski, C. F. (2008). Validation of high-resolution satellite rainfall products over complex terrain. International fournal of Remote Sensing 29: 4097-4110.

Dixit, P. N., Cooper, P.J. M., Rao, K. P. and Dimes, J. (2011). Adding value to field-based agronomic research through climate risk assessment: A case study of maize production in Kitale, Kenya. Experimental Agriculture 47: 317-338.

Ford, J. and Leggate, B. M. (1961). The geographical and climatic distribution of trypanosome infection rates in $G$. morsitans group of tsetse-flies (Glossina WIED. DIPTERA). Transactions of the Royal Society of Tropical Medicine and Hygiene 55: 383-397.

Fry, W. E. and Goodwin, S. B. (1997). Resurgence of the Irish Potato famine fungus. BioScience 47: 363-371.

Garrett, K., Forbes, G., Pande, S., Savary, S., Sparks, A., Valdivia, G., Vera Cruz, G. and Willocquet, L. (2009). Anticipating and responding to biological complexity in the effects of climate change on agriculture. IOP Conf. Series: Earth and Environmental Science 6 372007. doi:10.1088/1755-1307/6/7/372007.

Grimes, D. I. F. and Pardo-Igúzquiza, E. (2010). Geostatistical analysis of rainfall. Geographical Analysis 42: $136-160$.

Grimes, D. I. F., Pardo-Igúzquiza, E. and Bonifacio, R. (1999). Optimal areal rainfall estimation using raingauges and satellite data. Fournal of Hydrology, 222: 93-108.

Hartkamp, A. D., White, J. W. and Hoogenboom, G. (2003). Comparison of three weather generators for crop modeling: a case study for subtropical environments. Agricultural Systems 76: 539-560.

Haware, M. P. (1990). Fusarium wilt and other important diseases of chickpea in the Mediterranean area. In Present Status and Future Prospects of Chickpea Crop Production and Improvement in the Mediterranean countries, 61-64 (Eds M. C. Saxena, J. I. Cubero and J. Wery). Zaragoza: CIHEAM-IAMZ,

Homewood, K., Trench, P., Randall, S., Lynen, G. and Bishop, B. (2006). Livestock health and socio-economic impacts of a veterinary intervention in Maasailand: Infection-and-treatment vaccine against East Coast fever. Agricultural Systems 89: 248-271.

Huffman, G. J., Adler, R. F., Bolvin, D. T., Gu, G., Nelkin, E. J., Bowman, K. P., Hong, Y., Stocker, E. F. and Wolff, D. B. (2007). The TRMM multi-satellite precipitation analysis: quasi-global, multi-year, combined-sensor precipitation estimates at fine scale. Fournal of Hydrometeorology 8: 38-55. [See also: http://trmm.gsfc.nasa.gov/3b42.html]

Jésus, W. C., Valadares, R., Cecilio, R. A., Moraes, W. B., Vale, F. X. R., Alves, F. R., and Paul, P. A. (2008). Worldwide geographical distribution of black sigatoka for banana: predictions based on climate change models. Scientia Agricola 65: 40-53.

Jones, P. G. and Thornton, P. K. (2000). MarkSim: Software to generate daily weather data for Latin America and Africa. Agronomy fournal 92: 445-453.

Jones, P. G., Thornton, P. K., Diaz, W., and Wilkens, P. W. (2002). MarkSim, Version 1. A computer tool that generates simulated weather data for crop modeling and risk assessment. CIAT CD-ROM series, CIAT, Cali, Colombia.

Kousik, G. S., Thakur, R. P. and Subba Rao, K. V. (1988). Influence of environmental factors on production and dispersal of Tolyposporium penicillariae sporidia. Indian Fournal of Aerobiology 1: 85-91.

Lebel, T., Sauvageot, H., Hoepffner, M., Desbois, M., Guillot, B. and Hubert, P. (1992). Rainfall estimation in the Sahel: the EPSAT-NIGER experiment. Hydrological Sciences fournal 37: 201-215. 
Morton, J. F. (2007). The impact of climate change on smallholder and subsistence agriculture. Proceedings of the National Academy of Sciences 104: 19680-19685.

Mouliom Pefora, A. (1991). Effect of climatic factors on the development of Mycosphaerella fijiensis (black sigatoka disease) in banana (AAA) in Moungo, Cameroon (1987-1989). In Proceedings of IFS/CTA Regional Seminar Influence of the climate on the production of tropical crops, Ouagadougou, Burkina Faso. Stockholm/Ede.

NASA (2006). NASA Facts: TRMM Instruments. http://trmm.gsfc.nasa.gov/overview_dir/instrumentfacts.html [Accessed 15 November 2010].

Nene, Y. L. (1979). Proceedings of the Consultants' Group Discussion on the Resistance to Soil-borne Diseases of Legumes. Patancheru, India, International Crops Research Institute for the Semi-Arid Tropics, (ICRISAT), $\delta^{\text {th }}-11^{\text {th }}$ January 1979.

Nyvall, R. (1999). Field Crop Diseases Handbook, Iowa State University, Ames, USA.

Oerke, E. C., Dehne, H. W., Schohnbeck, F. and Weber, A. (1995). Crop Production and Crop Protection: Estimated Losses in Major Food and Cash Crops. Amsterdam: Elsevier.

Ojiem, J. O. (2006). Exploring socio-ecological niches for legumes in western Kenya smallholder farming systems. PhD thesis, Wageningen University, The Netherlands.

Otsyula, R. M. (1994). Development of an integrated bean root rot control strategy for Western Kenya. In Proceedings of a Working Group Meeting of Bean Breeders in the Eastern Africa Region. Kampala, Uganda, Centro Internacional de Agricultura Tropical, $30^{\text {th }}$ May $-2^{\text {nd }}$ Fune 1994.

Otsyula, R., Rubaihayo, P. and Buruchara, R. (2003). Inheritance of resistance to Pythium root rot in beans (Phaseolus vulgaris) genotypes. African Crop Science Conference Proceedings 6: 295-298.

Otsyula, R., Rachier, G., Ambitsi, N., Juma, R., Ndiya, C., Buruchara, R. A. and Sperling, L. (2004). The use of informal seed producer groups for diffusing root-rot resistant varieties during periods of acute stress, In Addressing Seed Security in Disaster Response: Linking Relief with Development, 69-89. (Eds L. Sperling, T. Remington, J.M. Haugen and S. Nagoda). International Center for Tropical Agriculture (CIAT), Cali, Colombia.

Otsyula, R. M. and Buruchara, R. (2001). Research on bean root rot in Kenya. In Proceedings of the PABRA Millennium Workshop. Arusha, Tanzania, $28^{\text {th }}$ May-1 ${ }^{\text {st }}$ June 2001, 159-166

Pieczarka, D. J. and Abawi, G. S. (1978). Influence of soil water potential and temperature on severity of pythium root rot of snap beans. Ecology and Epidemiology 68: 766-772.

Ramankutty, N., Evan, A. T., Monfreda, C. and Foley, J. A. (2008). Farming the planet: 1. Geographic distribution of global agricultural lands in the year 2000. Global Biogeochemical Cycles 22: 1-19.

Reddy, T. Y. and Sulochanamma, B. N. (2008). Effect of minimal amount of supplemental irrigation during drought stress on yield and quality of groundnut. Legume Research - An International Fournal 31 (2).

Rogers, D. J., Hay, S. I. and Packer, M. J. (1996). Predicting the distribution of tsetse flies in West Africa using temporal Fourier processed meteorological satellite data. Annals of Tropical Medicine and Parasitology 90: 225-241.

Spence, N. 2003. Characterisation and epidemiology of root rot diseases caused by Fusarium and Pythium spp. in beans in Uganda. Final Technical Report. Horticulture Research International, Wellesbourne, Warwick

van de Steeg, J. A., Herrero, M., Kinyangi, J., Thornton, P. K., Rao, K. P. G., Stern, R. and Cooper, P. (2009). The influence of climate variability and climate change on the agricultural sector in East and Central AfricaSensitizing the ASARECA strategic plan to climate change. Research Report 22. ILRI (International Livestock Research Institute), Nairobi, Kenya, ICRISAT (International Crop Research Institute for the Semi-Arid Tropics), Nairobi, Kenya, and ASARECA (Association for Strengthening Agricultural Research in Eastern and Central Africa), Entebbe, Uganda.

Teo, C.-K. and Grimes, D. I. F. (2007). Stochastic modelling of rainfall from satellite data. Fournal of Hydrology 346: 33-50.

Thakur, R. P., Rao, V. P. and King, S. B. (1991). Influence of temperature and wetness duration on infection of pearl millet by Claviceps fusiformis. Phytopathology 81: 835-838.

Thorne, V., Coakeley, P., Grimes, D. and Dugdale, G. (2001). Comparison of TAMSAT and CPC rainfall estimates with rain gauges, for southern Africa. International fournal of Remote Sensing 22: 1951-1974.

University of Reading (2008). Instat ${ }^{\mathrm{TM}}$ - an interactive statistical package. Statistical Services Centre, University of Reading, UK.

Williamson, S., Ball, A. and Pretty, J. (2008). Trends in pesticide use and drivers for safer pest management in four African countries. Crop Protection 27: 1327-1334.

Wortmann, C. S., Kirkby, R. A., Eledu, C. A. and Allen, D. J. (1998). Atlas of Common Bean (Phaseolus vulgaris L.) production in Africa, Cali, Colombia, CIAT. 